\title{
High survival rate of unfertilized mouse oocytes after vitrification
}

\author{
N. Nakagata \\ Central Laboratory of Medical Sciences, Division of Pathology, \\ Juntendo University School of Medicine, 2-1-1 Hongo, Bunkyo-Ku, Tokyo 113, Japan
}

\begin{abstract}
Summary. Unfertilized mouse oocytes were cooled rapidly by directly plunging them into liquid nitrogen, immediately after exposure to a highly concentrated solution (modified VS1: 2.53 M-dimethyl sulphoxide, 2.36 M-acetamide, $1.19 \mathrm{M}$-propylene glycol, $5 \cdot 4 \%(\mathrm{w} / \mathrm{v})$ polyethylene glycol $\left(M_{\mathrm{r}} 8000\right)$ in $\left.\mathrm{PBI}\right)$, and later warmed in a $37^{\circ} \mathrm{C}$ waterbath. After warming, 305 out of 348 oocytes $(87.6 \%)$ were morphologically normal.

After fertilization in vitro of cryopreserved oocytes, the proportions of pronuclear oocytes and 2-cell embryos 5 and $24 \mathrm{~h}$ after insemination were $81.6 \%$ (124/152) and $78.4 \%(120 / 153)$, respectively. All 2-cell embryos obtained from cryopreserved oocytes were transferred to the oviducts of pseudopregnant recipients and $45 \cdot 8 \%(55 / 120)$ developed to normal young.
\end{abstract}

Keywords: vitrification; rapid cooling; unfertilized mouse oocytes; in-vitro fertilization

\section{Introduction}

Since mouse embryos were shown to survive storage at $-196^{\circ} \mathrm{C}$ by the subsequent birth of live young (Whittingham et al., 1972), preimplantation embryos of many mammalian species have been successfully stored at $-196^{\circ} \mathrm{C}$ (Leibo, 1986; Friedler et al., 1988). Although the freezing of unfertilized mouse oocytes was reported by Tsunoda et al. (1976), Parkening et al. (1976), Whittingham (1977) and Glenister et al. (1987), the overall survival rates of the oocytes after thawing were low in these reports. Nakagata (1989) has demonstrated that it is possible to snap-cool 2-cell mouse embryos after brief, one-step exposure to a modified vitrification solution (VS1) (Rall \& Fahy, 1985) at room temperature.

In the present study the viability of unfertilized mouse oocytes has been examined.

\section{Materials and Methods}

Source of oocytes. $\mathrm{B} 6 \mathrm{C} 3(\mathrm{C} 57 \mathrm{BL} \times \mathrm{C} 3 \mathrm{H} / \mathrm{He}) \mathrm{F}_{1}$ hybrid mice (3-4 months old) were induced to superovulate with injections of 5 i.u. PMSG and 5 i.u. hCG $48 \mathrm{~h}$ apart. Intact cumulus masses were released from the excised oviducts into HTF medium (Quinn et al., 1985) containing $0.1 \%$ hyaluronidase $14-15 \mathrm{~h}$ after hCG. When the cumulus cells had been detached from the oocytes, the oocytes were washed 3 times in HTF medium $(0.2 \mathrm{ml} / \mathrm{wash})$ and incubated for $10-20 \mathrm{~min}$ in HTF medium containing $20 \%$ fetal calf serum (Gibco, Grand Island, NY, USA) at $37^{\circ} \mathrm{C}$ under $5 \%$ $\mathrm{CO}_{2}$ in air before cryopreservation.

Cooling and warming. The cooling and warming method used has been described previously (Nakagata, 1989). Between 20 and 25 cumulus-free oocytes in a small volume of HTF medium $(<1 \mu 1)$ were transferred into $20-30 \mu l$ of modified VS1 medium (2.53 M-dimethyl sulphoxide (DMSO), 2.36 M-acetamide, $1 \cdot 19 \mathrm{M}$-propylene glycol, $5.4 \%$ (w/v) polyethylene glycol $\left(M_{\mathrm{r}} 8000\right)$ in Medium PB1 (Whittingham, 1974), in sampling tubes (volume $0.5 \mathrm{ml}$ : Cat. No. 72.699, Sarstedt, Nümbrecht, West Germany) at room temperature and the samples were plunged directly into liquid nitrogen. The time of exposure of the oocytes to modified VS1 before cooling was $5-10 \mathrm{sec}$. The samples were stored for $1-3$ weeks before warming. The samples were warmed by direct transfer from liquid nitrogen to a $37^{\circ} \mathrm{C}$ waterbath 
and were immediately diluted with a single addition of $0.3 \mathrm{ml} \mathrm{Medium} \mathrm{PBl} \mathrm{containing} 0.3 \mathrm{M}$-sucrose when the samples began to liquefy $(\sim 5 \mathrm{sec})$. The contents of each tube were emptied into a watch glass and the tubes were rinsed once with $0.3 \mathrm{ml}$ Medium PBl containing $0.3 \mathrm{M}$-sucrose. The recovered oocytes were washed by transfer through $4 \mathrm{changes}$ of HTF medium $(0.2 \mathrm{ml} /$ wash) at room temperature, and the number of oocytes and their morphological appearance were recorded.

Fertilization in vitro and embryo transfer. The procedures for fertilization in vitro were essentially those described by Toyoda et al. (1971). Spermatozoa were obtained from the cauda epididymidis of 3- to 4-month-old ICR-JCL males and were suspended in a culture dish $(35 \times 10 \mathrm{~mm}$, Falcon) containing HTF medium covered with paraffin oil (Squibb), and incubated for $1 \mathrm{~h}$ at $37^{\circ} \mathrm{C}$ under $5 \% \mathrm{CO}_{2}$ in air. After the incubation, sperm concentration was adjusted to 150 cells $/ \mu 1$ in $0.4 \mathrm{ml}$ HTF medium. Morphologically normal cryopreserved oocytes were introduced into the sperm suspension. In addition, some untreated cumulus-free oocytes were inseminated (control), and others were exposed to the modified VSI medium, but not cooled (solution control). Following incubation for $5 \mathrm{~h}$, approximately half the number of the oocytes were mounted in toto on a slide, stained and examined for the assessment of fertilization. The remainder were further cultured for $19 \mathrm{~h}(24 \mathrm{~h}$ after insemination) and 2-cell embryos were recorded. Oocytes that developed to 2-cell stages were transferred to the oviducts of pseudopregnant females on the day of finding the vaginal plug (Day 1 of pseudopregnancy).

Statistical analyses. Data were analysed by $\chi^{2}$ tests.

\section{Results}

Nearly all (348/361) of the cryopreserved oocytes were recovered and exhibited a normal morphology $(87.6 \%, 305 / 348)$ after warming and dilution (Fig. 1).

\section{Fertilization in vitro of cryopreserved oocytes}

The results when the cryopreserved oocytes were examined 5 and $24 \mathrm{~h}$ after insemination are summarized in Tables 1 and 2 and Figs 2 and 3. In the cryopreserved oocytes, the proportions of pronuclear oocytes and 2-cell embryos 5 and $24 \mathrm{~h}$ after insemination in vitro were $81.6 \%(124 / 152)$ and $78.4 \%(120 / 153)$, respectively. There were significant reductions in the percentages of pronuclear oocytes and 2-cell embryos when compared with those of the untreated oocytes (control) $(P<0.05)$, but no significant changes when compared with those of the oocytes exposed to the modified VS1, but not cooled (solution control) $(P>0.05)$.

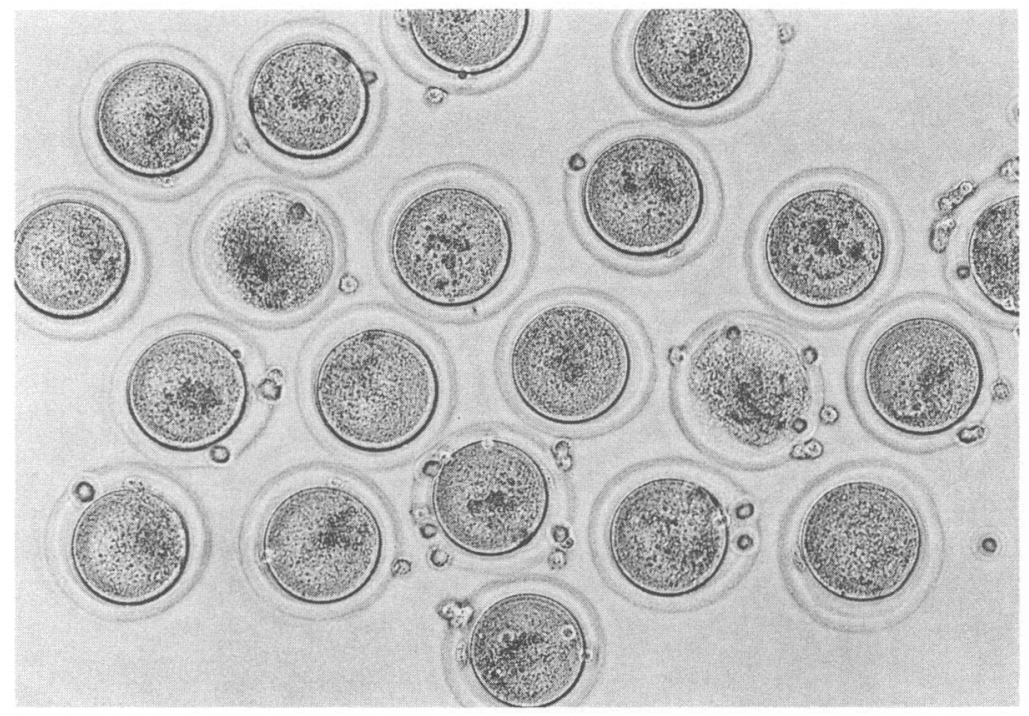

Fig. 1. Appearance of cryopreserved mouse oocytes after warming. Most of the cryopreserved oocytes were morphologically normal. 
Table 1. The fertilization rate of cryopreserved mouse oocytes $5 \mathrm{~h}$ after insemination in vitro

\begin{tabular}{lcrcc}
\hline \multirow{2}{*}{$\begin{array}{l}\text { Treatment } \\
\text { group }\end{array}$} & $\begin{array}{c}\text { No of } \\
\text { oocytes } \\
\text { examined }\end{array}$ & & \multicolumn{3}{c}{ No. of oocytes fertilized* } \\
\cline { 3 - 5 } & 152 & $124(81 \cdot 6)$ & 117 & 7 \\
\hline Cryopreserved & 90 & $77(85 \cdot 6)$ & 72 & 5 \\
Solution control & 87 & $84(96 \cdot 6)$ & 80 & 4 \\
Control & & &
\end{tabular}

*Pronuclear oocytes (oocyte with sperm tail(s), male and female pronuclei).

Table 2. Development of 2-cell embryos from cryopreserved mouse oocytes $24 \mathrm{~h}$ after insemination in vitro

\begin{tabular}{lcc}
\hline $\begin{array}{l}\text { Treatment } \\
\text { group }\end{array}$ & $\begin{array}{c}\text { No. of } \\
\text { oocytes } \\
\text { examined }\end{array}$ & $\begin{array}{c}\text { No. (\%) of } \\
\text { oocytes developed } \\
\text { to 2-cell stage }\end{array}$ \\
\hline Cryopreserved & 153 & $120(78 \cdot 4)$ \\
Solution control & 88 & $74(84 \cdot 1)$ \\
Control & 80 & $78(97 \cdot 5)$ \\
\hline
\end{tabular}

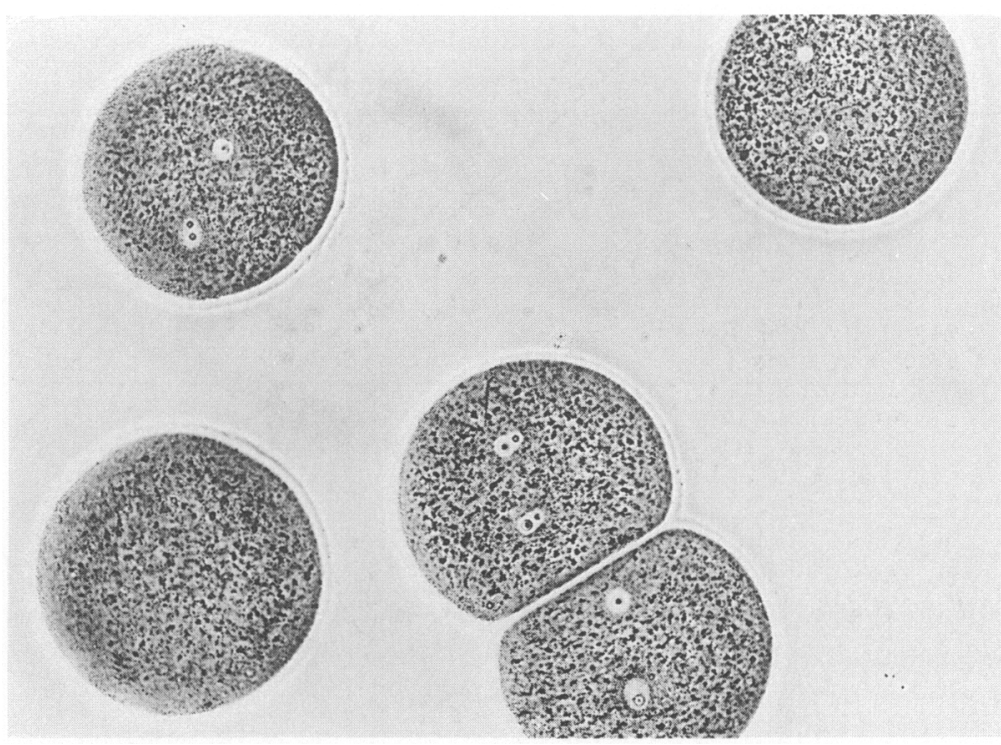

Fig. 2. Appearance of cryopreserved and in-vitro fertilized mouse oocytes at the pronuclear stage $5 \mathrm{~h}$ after insemination in vitro. 


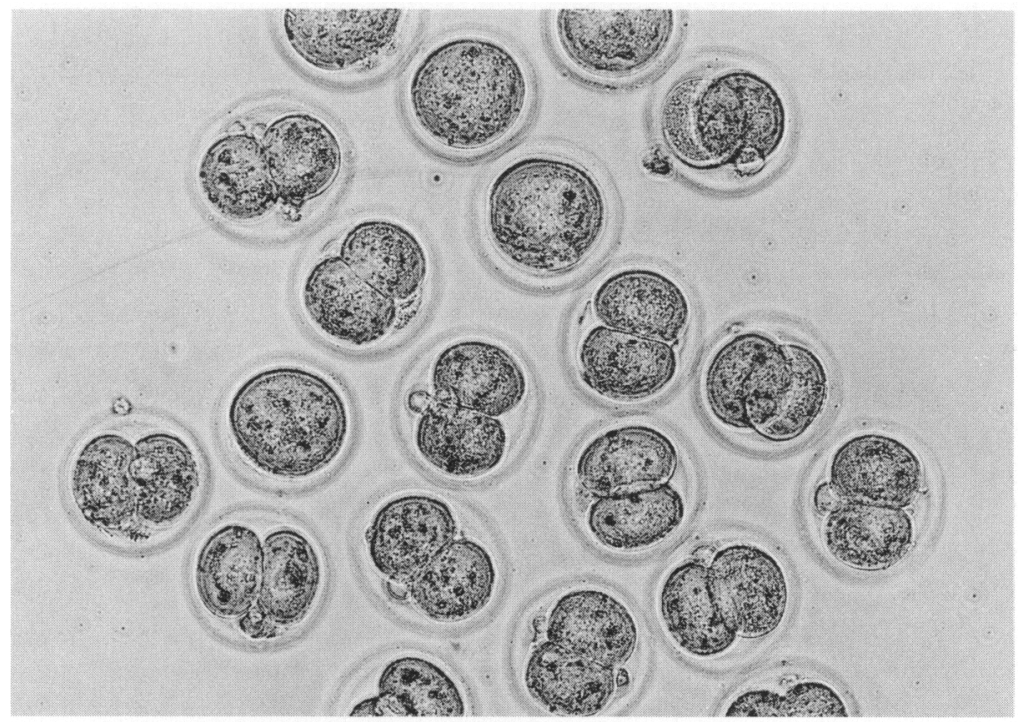

Fig. 3. Appearance of cryopreserved and in-vitro fertilized mouse oocytes at the 2-cell stage $24 \mathrm{~h}$ after insemination in vitro.

\section{Transfer of cryopreserved oocytes}

The development of 2-cell embryos from cryopreserved oocytes fertilized in vitro after transfer is shown in Table 3. All 2-cell embryos obtained from cryopreserved oocytes were transferred to 11 pseudopregnant recipients and $45 \cdot 8 \%(55 / 120)$ of the 2-cell embryos developed to normal young. There was no significant difference in rate of survival to normal young between the cryopreserved oocytes and the oocytes exposed to modified VS1, but not cooled (solution control) $(P>0.05)$, but survival was significantly lower than that of the untreated oocytes (control) $(P<0.05)$.

Table 3. Development to live young of 2-cell embryos derived from cryopreserved mouse oocytes after transfer to pseudopregnant recipients

\begin{tabular}{lccccccc}
\hline \multirow{2}{*}{$\begin{array}{l}\text { Treatment } \\
\text { group }\end{array}$} & $\begin{array}{c}\text { No. of } \\
\text { recipients } \\
\text { used }\end{array}$ & $\begin{array}{c}\text { 2-cell embryos } \\
\text { transferred }\end{array}$ & $\begin{array}{c}\text { No. of } \\
\text { which delivered } \\
\text { live young }\end{array}$ & 120 & \multicolumn{2}{c}{ No. of live young - } \\
\cline { 5 - 8 } & Cryopreserved & 11 & 74 & 9 & 30 & 25 & $55(45 \cdot 8)$ \\
Solution control & 7 & 78 & 7 & 13 & 19 & $32(43 \cdot 2)$ \\
Control & 7 & & & & 27 & 20 & $47(60 \cdot 3)$ \\
\hline
\end{tabular}

\section{Discussion}

The present study demonstrates that unfertilized mouse oocytes can be cryopreserved successfully using the simple technique of vitrification and these cryopreserved oocytes can develop into normal, live young after in-vitro fertilization and embryo transfer.

Tsunoda et al. (1976) reported that mouse oocytes can be successfully preserved at $-70^{\circ} \mathrm{C}$ and $-196^{\circ} \mathrm{C}$ by the slow freezing and slow thawing method of Whittingham et al. (1972), but the survival rates after thawing were low and only 4-13\% of the morphologically normal oocytes can 
be fertilized in vitro. Whittingham (1977) and Glenister et al. (1987) also reported that the percentages of morphologically normal oocytes after thawing were between $65 \%$ and $76 \%$ after being stored at $-196^{\circ} \mathrm{C}$ by similar methods (Whittingham et al., 1972). Furthermore, these authors report that a proportion of these frozen-thawed oocytes can develop to live fetuses or young after in-vitro fertilization and transfer of 2-cell embryos. However, this slow freezing and slow thawing method is time-consuming, and the overall survival rates of frozen-thawed oocytes are low compared with those of frozen-thawed embryos (Leibo, 1986; Friedler et al., 1988).

A successful rapid cooling method for 8-cell mouse embryos has been reported, in which freezing occurred in a mixture of $3 \mathrm{M}$-glycerol and 0.25-0.5 M-sucrose (Takeda et al., 1984; Széll \& Shelton, 1986). However, there are no reports of the cryopreservation of oocytes using a similar method. The method of rapid cooling presented here is very simple, is not time-consuming, and results in a high survival rate of mouse oocytes after thawing. Therefore, it may be a good technique for frozen storage of mouse oocytes. Although the mouse oocyte survives cooling and warming, few hamster oocytes $(<5 \%)$ exhibit evidence of fertilization after cryopreservation by the technique described here (unpublished observations). The sensitivity of the oocytes to cooling and warming may be different between species. Further experiments are required to establish a suitable procedure of cooling and warming the oocytes of different species.

I thank Dr Yutaka Toyoda (Institute of Medical Science, University of Tokyo, Tokyo, Japan) and Dr Yoshiro Fukuda, and Mrs Yaeko Murata (Juntendo University, School of Medicine, Tokyo, Japan), for their advice and help.

\section{References}

Friedler, S.F., Giudice, L.C. \& Lamb, E.J. (1988) Cryopreservation of embryos and ova. Fert. Steril. 49, $743-764$.

Glenister, P.H., Wood, M.J., Kirby, C. \& Whittingham, D.G. (1987) Incidence of chromosome anomalies in first-cleavage mouse embryos obtained from frozenthawed oocytes fertilized in vitro. Gamete Res. 16, 205-216.

Leibo, S.P. (1986) Cryobiology: preservation of mammalian embryos. Basic Life Sci. 37, 251-271.

Nakagata, N. (1989) Survival of 2-cell mouse embryos derived from fertilization in vitro after ultra rapid freezing and thawing. Jap. J. Fert. Steril. 34, 470-473.

Parkening, T.A., Tsunoda, Y. \& Chang, M.C. (1976) Effects of various low temperature, cryoprotective agents and cooling rates on the survival, fertilizability and development of frozen thawed mouse eggs. $J$. exp. Zool. 197, 369-374.

Quinn, P., Kerin, J.F. \& Warnes, G.M. (1985) Improved pregnancy rate in human in vitro fertilization with the use of a medium based on the composition of human tubal fluid. Fert. Steril. 44, 493-498.

Rall, W.F. \& Fahy, G.M. (1985) Ice-free cryopreservation of mouse embryos at $-196^{\circ} \mathrm{C}$ by vitrification. Nature, Lond. 313, 573-574.
Széll, A. \& Shelton, J.N. (1986) Sucrose dilution of glycerol from mouse embryos frozen rapidly in liquid nitrogen vapour. $J$. Reprod. Fert. 76, 401-408.

Takeda, T., Elsden, R.P. \& Seidel, G.E., Jr (1984) Cryopreservation of mouse embryos by direct plunging into liquid nitrogen. Theriogenology 21, 266, abstr.

Toyoda, Y., Yokoyama, M. \& Hosi, T. (1971) Studies on the fertilization of mouse eggs in vitro. I. In vitro fertilization of eggs by fresh epididymal sperm. Jap. $J$. Anim. Reprod. 16, 147-151.

Tsunoda, Y., Parkening, T.A. \& Chang, M.C. (1976) In vitro fertilization of mouse and hamster eggs after freezing and thawing. Experientia 32, 223-224.

Whittingham, D.G. (1974) Embryo banks in the future of developmental genetics. Genetics, Princeton 78, 395-402.

Whittingham, D.G. (1977) Fertilization in vitro and development to term of unfertilized mouse oocytes previously stored at $-196^{\circ}$ C. J. Reprod. Fert. 49, 89-94.

Whittingham, D.G., Leibo, S.P. \& Mazur, P. (1972) Survival of mouse embryos frozen to $-196^{\circ} \mathrm{C}$ and $-269^{\circ} \mathrm{C}$. Science, NY 187, 411-414.

Received 13 January 1989 